\title{
Local farmers vs. environmental universalism: conflicts over nature conservation in the Parco Nazionale dei Monti Sibillini, Italy
}

\author{
Sandro Piermattei ${ }^{1}$ \\ Università degli Studi di Perugia, Italy
}

\section{Introduction}

There is an important literature in the social sciences that is concerned with questions of social equality within protected areas and resulting from conservation policies (Anderson and Berglund 2004; Papa 2004; Vaccaro et al. 2013). As Ambinakudige puts it, talking about Adivasi communities in India; "Unfortunately, most conservation strategies involving the protection of habitats and species through the demarcation of Protected Areas also elevate levels of distress for poor people living in and around them by foreclosing access" (Ambinakudige 2011: 2). In too many cases, a reinforcement of unequal power relationships has been observed along with a worrying lack of representative democracy within protected area management strategies, supporting the perception that conservation is a means to strengthen the elite and benefit the rich (Agrawal and Redford 2009; Annear 2009). Establishing a protected area can restrict rural peoples' access and use of resources through legislation, enforcement, and privatization (Dowie 2005; Greenough 2003; Igoe 2003), or alienate the land-use rights of native people (Agrawal and Ostrom 2001), even by criminalization of local land-use practices (Klooster 2000; Freedman 2002). These situations are not only challenging the moral basis of worldwide nature conservation, but are also resulting in a vicious circle, as in the case that I will examine. As Agrawal and Redford have stated, "some conservation programs are likely to create anger and bitterness", thus local residents could "have strong incentives to destroy the wildlife and resources within protected areas" (2009: 6). These deliberate acts produce a negative public opinion of local communities, fueling the criminalization of their supposed anti-conservationist and utilitarian attitudes towards the environment.

After more than ten years of research in the protected area of the Parco Nazionale dei Monti Sibillini, north-east of Rome in the Central Apennines of Italy, I have identified how the creation of the park has reinforced a certain local order of power relations (even though I have not observed forced displacements of people or alienation of land-use rights). This order tends to prevent the concrete bottomup participation of specific social groups in policy and decision-making. In particular, a large majority of the local farmers and shepherds are politically marginalized. These people are directly involved in landuse practices and are suffering increasing and significant losses to livelihoods and agricultural incomes. Losses are mainly due to interactions between livelihood activities and wildlife, or they are due to a reduction of access to areas set aside for conservation, just as numerous studies have documented elsewhere in the world (Heatherington 2010; McLean and Straede 2003; Rao et al. 2002).

Local farmers vary in their capacity to participate actively in political negotiations within the park's administration and their relationships are often ambiguous. The aim of this article is to examine local power relations in order to focus on those ambiguities and contradictions concealed behind the generic formula of the conflict between local farmers and natural parks. Starting with some consideration of local history, a particular focus will be placed on the local population in order to analyze how this group is socially and economically stratified and how they interact politically with local authorities and park managers. I will then examine the key political role of local officials. To conclude I will discuss the park's capability for building a strong social consensus towards nature conservation and sustainable development goals.

\section{The local farmers' power relations}

In their impressive overview on the literature of protected areas, West et al. stated that: "The absence of some regions from the protected-area literature may reflect differences between countries. The lack of European regions in the literature demonstrates the relative lack of hardship created by protected areas on this continent." (West, Igoe and Brockington 2006: 258). I have to disagree in part. There are substantial differences between different contexts in which nature protection is practiced, and different national policies, and even different ways in which the same policies are implemented. For instance, the same Italian national legislation shows very different results in different regions from south to north, from

\footnotetext{
${ }^{1}$ Dr. Sandro Piermattei, Adjunct Professor of Environmental Anthropology, Sezione Antropologica - Dipartimento Uomo \& Territorio, Università degli Studi di Perugia, Perugia, Italy. Email: sandro.piermattei "at" alice.it. Field research in several regions and protected areas in central and southern Italy has been supported by a PhD grant by the Università degli Studi di Siena and a five-year research grant as member of a national interdisciplinary project on cultural and environmental heritage conservation. I would like to thank all my field-informants, my research colleagues, and Prof. Cristina Papa for her guidance, wisdom and support. I also thank the anonymous reviewers and the editors for their suggestions and comments. This paper is in Koensler A. and Papa C. (eds.) "After anthropocentrism? Environmental conflicts, social movements and power," special section of the Journal of Political Ecology 20: 255-341.
} 
coastal and marine protected areas to the mountains. But the absence of European regions in the protected area literature remains, in my opinion, a curious literary riddle. Local communities are affected by protected areas, although 'European hardship' is less dramatic than those reported by studies on other continents. There are significant differences between the contexts in which "indigenous peoples are dependent on traditional knowledge and practices in caring for their traditional territories, and for the harvesting of wild food and animals, medicines, water, and other basic needs" (Langton, Rhea and Palmer 2005: 24) and European conservation regions where local communities are ultimately much less dependent on the natural environment for subsistence and income (Vaccaro and Beltran 2010). Even specific social groups still relying on the environment to make profit, like farmers and shepherds, are not completely dependent on it. As Berkes has argued, we are talking about communities that are "multidimensional, cross-scale social-political units or networks changing through time" (2004: 623).

Local communities living in the territory of the Parco Nazionale dei Monti Sibillini (Figure 1) are no longer primary subsistence producers; these are modern western communities fully integrated within the context of the market economy, although many are still employed in agriculture and in grazing and logging activities. In the last century, many young Italians, attracted by modern lifestyles, migrated to Rome and other towns of the surrounding areas. They were looking for employment in commercial activities or in industrial and artisanal manufacturing in order to earn a secure salary and escape from the harsh working conditions in the mountains. After World War II, when most rural household economies were still dependent on family labor, a massive depopulation caused a serious crisis for agricultural and livestock production. Agriculture in these limestone mountains is difficult to modernize even with modern technology. Most of the region has poor and rugged terrain subject to landslides and earthquakes, and it is covered by forest interspersed with small plots that are difficult to access with agricultural machinery. The only exceptions are some karstic areas: the wide and fertile intermountain plains of Castelluccio, Santa Scolastica, Colfiorito and Macereto, where is possible to practice the most intense and profitable agricultural activities, using modern mechanical equipment.
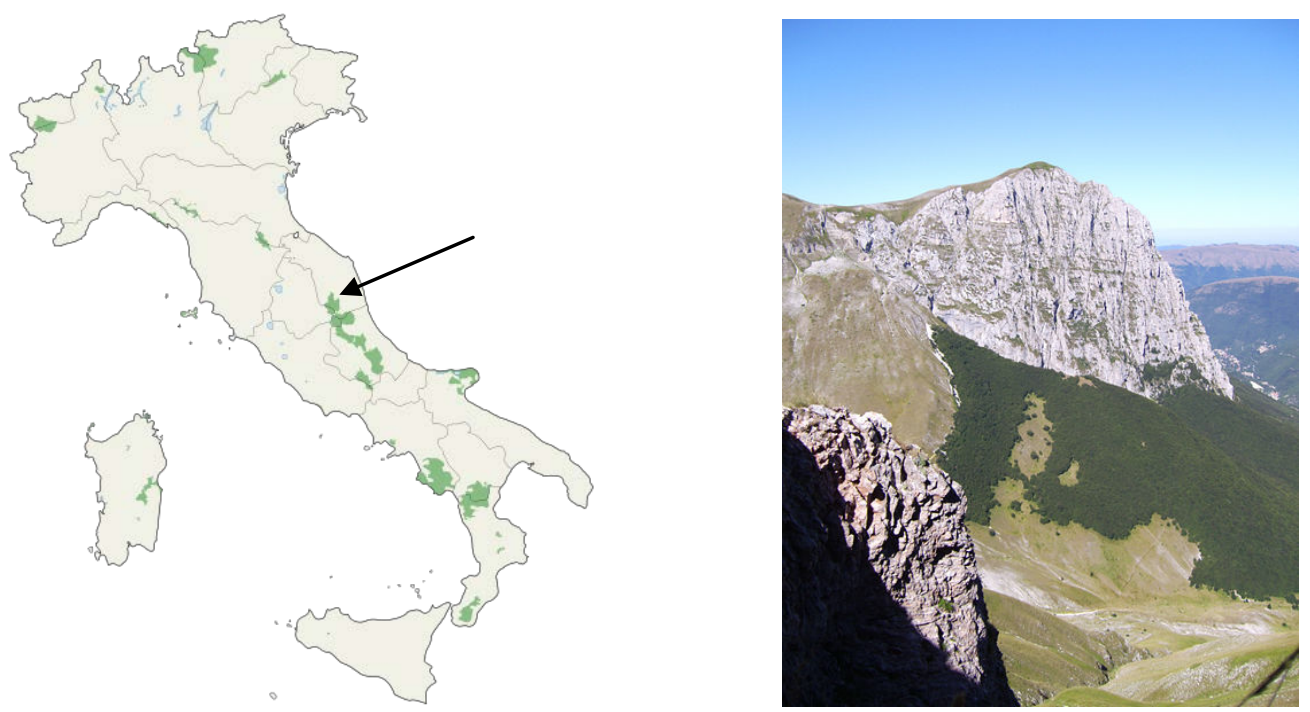

Figure 1: a) National Parks in Italy, and the Parco Nazionale dei Monti Sibillini b) Monte Bove Nord, Monti Sibillini. Source: Wikipedia Commons.

As a result, social stratification has developed among local farmers and shepherds. On the one hand, there are the majority of small farmers, most of them the first-born among their siblings, with low incomes and a low level of formal education. They own small plots or they utilize others from communal areas. They usually supplement their incomes with wage labor in building and construction, in small local manufacturing or in grazing and logging activities on bigger farms. Small farmers also practice family horticulture for their own consumption and for sale. Their children are usually encouraged to study in order to find a job outside agriculture.

On the other hand, the biggest local land-owners and entrepreneurial farmers manage diversified productive activities, including rural tourist facilities. Large scale farming and grazing is practiced with modern techniques and is often financially supported by European subsides for organic agriculture and quality foodstuffs, according to European Regulation $N^{\circ} 2092$ of 1991. Family members are still involved in entrepreneurial activities and part of the work is done by seasonal external workers. Some of these farmers have a higher education and their children are often encouraged to study law, agricultural science 
or economics to capitalise on a set of skills that can be used within local and trans-local networks, directly on the farm or outside it.

These social distinctions are crucial to understanding how the local debate on agro-environmental management is socially and politically structured. An example is the issue of sustainable and quality agriculture, which is used to implement environmental management, conservation and control within the territory. Agriculture or rather, small scale, organic and low input/impact farming are recognized by EU and Italian policies to be the main tools for environmental and landscape conservation and important in hydrogeological risk management. This latter feature is especially important in the context of climate change and, in particular, in terms of woodland and river and creek bank management. Quality food production, instead, has to do with health and safety for consumers and an increased competitiveness for European quality products but this, in turn, actually helps to conserve small-scale and quality farming. Traditional foods are an important component of the tourism offering. In fact, basing local development on tourism connected to the park's natural attractions entails sustaining and developing tourism facilities in particular agri-tourist farms, where it is possible to offer traditional foods as well.

These crucial issues of the agro-environmental debate have been ignored for years by the park administration. The policies of this protected area has been always geared towards protecting the environment, understood above all as wilderness, and promoting eco-tourism, but very little has been done to support and enhance organic agriculture. Even cultivated biodiversity (Brookfield 2001), which has always been preserved spontaneously by farmers as part of their family and farmland heritage, has not been the focus of research nor of conservation policies by the park. It is only in the last few years that the park board has planned a project to promote farming innovation and to study the commercial potential of those local crops considered to be economically important. Nevertheless, the park board and the farmers' unions involved in these programs seem to be supporting big farms rather than small-scale operations. In fact, local entrepreneurs are often asked for expensive farm renovations to comply with European and Italian organic farming and health regulations, leaving no chance for small farmers to comply (Papa 1999; Piermattei 2006, 2007). It is not hard to predict that the benefits of these policies will be unequally distributed and, obviously, this gives rise to criticisms and hostile attitudes towards the protected area by the majority of local farmers (Piermattei 2006). Indeed, for small farmers, opportunities to practice organic agriculture or to start an agri-tourist activity are often poor because they lack the money or legal and technical assistance from the farmers' unions and the agriculture agencies. The more entrepreneurial and larger farmers have the economic resources, the social relations and the political and technical competence to move themselves into the bureaucracy of EU and regional funding for rural development.

The more entrepreneurial farmers see the national park as a marketing opportunity for more commercially valuable products, but in return they offer few real guarantees that they are effectively implementing EU organic farming regulations. Moreover, research on conservation and the enhancement of local cultivated biodiversity is more likely to lead to benefits for bigger farms and industrial scale farming. We have a paradoxical situation where local cultivated biodiversity has mainly been conserved by older and smaller farmers who, in addition, already practice organic farming. Apart from the use of modern sowing, plowing and harvesting equipment, no pesticides or chemical fertilizers have ever been used on a large scale by the traditional local farmers. Soil conservation and, of course, the wild flora and fauna is the evidence - a fact that even park administrators and ecologists recognize.

Give this state of affairs it is curious that small farmers are being systematically left out of sustainable agriculture programs and that the park administration hasn't acted in their defense, by trying to obtain exemptions to the existing Italian and European regulations covering sustainable and quality farming. It is contradictory that the park administrators tend to rhetorically support a modern entrepreneurship, which is too often reported in local narratives and newspapers to be speculating with EU subsidies for organic agriculture in ways that are less than honest. The impression is that, perhaps, it is more economically and politically convenient to invest large amounts of money on a limited number of big farms.

These contradictions are easily explained if we take into account the differences between these two groups of farmers in terms of their tactical attitudes towards the local government and the park management. In particular, small farmers seem to be politically marginalized. Left behind, they are opportunistically used or evoked as interlocutors in order to coagulate political consensus. In fact, they take part to the local patronage relationships, giving or denying consensus on the base of personal fiduciary relations and kinship ties. The second group of farmers and land-owners, instead, is more politically influential. They can consistently mobilize economic interests and they can even manipulate local patronage relationships. Indeed, there are many cases of entrepreneurial farmers who are active participants in local political life, as union representatives or even as mayors, consultants or councillors. Within this context, the attitudes towards the park change, depending on specific circumstances and on the contingent political position held by individuals within the broader context of local power relations.

Although farming is not the only income source in the region, the two groups of local farmers behave and react in different ways regarding environmental protection and tourism promotion. The introduction of environmental restrictions, and damage to crops and livestock from wild animals produce very different impacts. Smaller operators appear more sensitive to restrictions and to damage. Entrepreneurial farmers and the biggest land-owners are more protected because they can rely on different agricultural and grazing activities in order to diversify their sources of income. They even tend to exploit the concerns of small farmers to achieve political consensus and to open spaces of negotiation 
with the park management. The local authorities, for their part, play an ambiguous role in dealing with these relations of power.

\section{The involution of local power relationships}

At first glance, the structure of the conflict between the park and the local farmers seemed very evident from the narratives collected during my fieldwork and from public debates. Nevertheless, as I observed the social context in which this conflict is played out more closely, I could see that it is more blurred than it may seem. In the twists and turns of day-to-day social life, the divisions between actors lose substance and are more fluid. People operate in both the agricultural and political arenas, and there are complex political affiliations, kinship ties, and friendships. A key role is played by the category of the local authorities that comprise mayors, councillors, river basin managers, union representatives, and common properties administrators. These people, who often come from the land-owning entrepreneurial farmers' group, have to respond to their electoral bodies that include small farmers. They also find themselves negotiating and producing political and social relations with the park management.

Some former local administrators constantly stressed that the political management of the territory was more direct and less bureaucratic today than in past decades. 'Trust' is the keyword;

...once administrators were really trusted, because people knew them and acknowledged them as a genuine part of the community. Take me, for instance, a real farmer in a community of farmers, one who has become mayor and, at the same time, head of the syndicate and president of the body for the management of soils and pastures of this municipality.

My informant had in mind his many years as local leader of the most important Italian political party after World War II, Democrazia Cristiana. His role as head of a well-populated mountain community made him an important local player for his party. This resulted in privileged contacts with key figures of national Italian politics in the Fifties and Sixties. These were years of easy political negotiations, when political patronage played a significant role in obtaining favors and funds for the community and in skipping the complicated procedures of national bureaucracy.

Today's local administrators look back with admiration at that political era. The mountains were filled with people and they had real power, even on a national scale. But over the last five decades, rural depopulation has politically marginalized the farming community. It is not surprising therefore that the multiplication of administrative bodies, both nationally and locally, and, in particular the establishment of the national park, are seen as sources of disempowerment. An increase in political influence over the last twenty years is evident among the most important land-owners and farmers. Even though the management of the local environment is entrusted to an entity that should operate in the national interest, local patronage relations are still operating and are still lively.

Evidence for this can be found in the ecological and political history of Monti Sibillini. In this region, the fate of agriculture still remains a critical issue linked to rural depopulation and to the problem of ecosystem balance, protection and control. The local landscape, as in many other contexts of the Italian Alps and Apennines, is a product of the historical interactions between local rural communities and their surrounding environment. For many centuries, men and women have deeply marked the land with their constant presence, such that the story is was of an environment strongly populated and exploited. After World War II, the increasing industrialization of the country and the resulting de-ruralization processes gave rise to mountain depopulation, which has become a real problem for these fragile ecosystems. Sibillini's natural environments today have become 'wild' and uncontrolled because of rural depopulation, and this is leading to more hydrogeological risks, ecological simplification and erosion of biodiversity.

For instance, the definite decline of high-altitude cultivation (in some cases well above 1,400 meters) has contributed to the loss of many bird species and other small animals that were a source of food for other predators. Cultivated local biodiversity was dramatically lost, even though the region is still rich in natural and cultural beauty and other species. ${ }^{2}$ Between the 1970s and 1980s, an intense political debate occurred. This led in the early 1990s to the establishment of a protected area of national interest in the hope of building a new strategy for local development and encourage young people to stay and take care of the landscape. The challenge was to develop political and social strategies "to involve the local rural communities directly in the nature conservation agenda" (Nardoni 1999), according to the principles of an enhancement of local farmers' ecological role and of their traditional environmental knowledge. Such principles are even supported by national and European regulations on nature protection (Piermattei 2007).

For the local rural communities, lobbying for the establishment of a protected area literally meant fighting to defend the landscape and the territory. The common enemies of farmers and environmental associations were the local state and administrations and their patronage relationships with contractors and builders (Nardoni 1999). Park managers, especially those who took part in the movement for the

\footnotetext{
${ }^{2}$ Wild flora and fauna include particularly interesting species - copses of high-altitude chestnuts and beech trees (Castanea sativa, Fagus sylvatica), and animals including the eagle (Aquila chrysaëtos), wolf (Canis lupus), bear

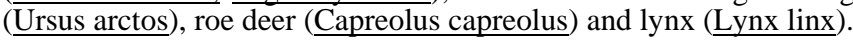


establishment of the protected area, argue that past local governments were only interested in commercial exploitation of natural resources. At that time, indeed, modernization meant new roads and new towns in order to attract tourism and investments. This development model didn't work, however. The competitive pressure in the tourism sector by some Alpine ski resorts further north soon put the local tourist offer out of business. The Italian Alps were already well equipped in terms of infrastructure and far more attractive in terms of winter sports. As a result there is still unused infrastructure and abandoned settlements marking some of the most beautiful local areas of the Park. They are symbols of an ineffective tourism development strategy.

Support for the creation of a protected area in the Sibillini Mountains required environmental associations to enlist the support of supposedly conservative local communities. At that time even the reluctance of farmers to innovate was perceived as useful for the political goals of the environmental associations. The challenge was ambitious even in political terms: the protected area should achieve good conservation principles, but also the establishment of a new land management framework characterized by equality, transparency and, above all, participation. In different terms, the park's policy had to transcend the supposed amoral 'familism' of local politicians (Herzfeld 1992): a common interest on the environment should prevail over the logic of local interests and patronage relationships if the protected area became a nationally recognized institution.

Unfortunately, the park's establishment in 1990 coincided with the approval of new national legislation on protected areas, and it was subject to these regulations. Observing the evolution of local power relations, it is evident that the political axis of negotiations with the newborn national park's administration moved from control by local rural communities, as originally envisaged, to new local government officers. The legislation enforces a vision of participative management as based exclusively on an executive and consultant body - ironically called Comunità del Parco or 'Park Community' - in which all the mayors and other representatives from the area's local administrations vote and discuss every program, regulation or project proposed by the park managers. Every decision by the local administration in which the park has legal competence has to be discussed and approved by the same bodies. In this sense, local history tells that, after the establishment of the national park, the dialogue with local communities, and in particular with farmers and shepherds faded out. Bottom-up participation has been replaced with exhaustive discussion and control within a narrowly circumscribed group of key actors and administration representatives.

It was almost unavoidable that the establishment of the park would lead to an increase of administrative control of local communities. Local mayors and the representatives of the regional bodies, taking part to the Comunità del Parco, are able to access national and European funds, and to coopt confidants, or each other, into key positions of the park's organization. Local government officers can even paralyze political action, engaging the park managers in continuous and strenuous negotiations while being politically obstructive. Such behavior has resulted in widespread disillusionment among the local population, as local development issues have not been addressed by the scarce funding coming from the Ministry of Environment. This again strengthens the capacity of the local government actors to influence and control the political consensus. This is why there is a concrete interest in fuelling a conflict between the farmers' private law concept of the territory and the ecologists' conception of the natural environment as a public good. Depending on specific political opportunities and circumstances, the mayors can play an important - but too often ambiguous - ecopolitical role as arbiters and mediators between parties. They talk about local heritage as something that can and must become part of what is offered as part of the international tourism campaign. But they also support the farmers' claims for private property rights, since these are greatly limited and regulated by the park. They share the ecologists' concern to insure democratic management of environmental resources - buttressed by scientific objectivity - while also recognizing farmer's local knowledge arising from their day-to-day work on the land.

Thus, local governments play a decisive role in dividing the ecopolitical field, widening the distance between farmers and the park's administration. An example is the local debate about wild fauna management. Farmers feel injustice and frustration because local development goals have been overlooked for too many years by the park administration, whereas ambitious and expensive projects have been undertaken to reintroduce animal species which have been extinct in this territory for centuries, to build hiking trails for nature walks in the mountains, to monitor the possibility for a return of bears from the Southern Apennines. The administration's vision of 'nature' is very different to that of small agricultural households who have occupied the land for centuries.

Farmers are worried about the large presence of boars, formerly an alien species in this territory. The original Italian species (Sus scrofa majori) has lived for centuries in a very restricted area in Tuscany. It was after World War II that many Italian hunting associations began to import a different kind of boar from Eastern Europe (Sus scrofa). Unfortunately, this species - stronger, bigger, more voracious and even more prolific than its Italian counterpart - spread all over Italy in just a few decades. This situation has especially concerned mountain national parks where, protected from hunters' rifles, the boars have multiplied quickly. The park's zoologists have found evidence that boars have become an important source of food for wolves. They suggest an ecological balance between two species which have been always seen as a threat to grazing and agriculture. But farmers and shepherds disagree with this theory. First of all, they observe that wolves' attacks on livestock continue (and in fact, they can only attack very old, young or sick boars) and that crops, pasture and woodland are still damaged by boars. This is why the 
protected area is now introducing other natural wolf prey - deer (Cervus elaphus) and chamois (Rupicapra rupicapra). Secondly, even though shepherds and farmers conceive wolves as a threat to their livestock, they admire and respect an animal that is a natural part of the environment and even a part of their social history and identity (Papa 1993). Boars, instead, are thought of as a signifier of environmental degradation, not simply because they destroy habitat, but because they don't belong to the traditional local fauna. Local farmers and shepherds therefore feel a strident contradiction between their historical experience of the environment and one produced within the protected area and, therefore, they pose questions about what kind of nature the national park is producing. They agree that the main role of this institution is that of protecting the existing local flora and fauna. In many cases, they are even willing to accept the use of the local flora and fauna as tourism attractions or educational tools. Nevertheless, the protection of formerly alien animal species as well as the introduction of other animal species that were extinct in the area for centuries are perceived as not coherent with a conservation principle but with the creation of a sort of zoo for tourists and professional ecologists.

This kind of representation is often suggested, supported and politically legitimated by some local authorities in public speeches and even in the columns of the local newspapers. In many cases they are the most influential entrepreneurial and land-owning farmers, especially those who are closer to small farmers; political actors who have an interest in the redefinition of park's regulations, for instance those regarding the ban on hunting. After years marked by an uncontrolled increase of boar numbers, the park managers, under the political pressures from local authorities, farmers and hunting associations, have decided to introduce programs for selective hunting in the park territory. Local farmers and hunters have been involved, trained and organized under the guidance of a group of park zoologists and it is evident that boar numbers cannot be controlled without their help. Crops and woodlands are still suffering damage and selective hunting appears to be too dependent on the park administration's insufficient funds. Thus, depending on contingent opportunities and circumstances, the local authorities can push the park administration to open further spaces of negotiation.

Taking into account the current critical financial situation of national bodies in an over-indebted country like Italy, it is legitimate to ask if different investment planning, with farmers and shepherds directly involved in fauna and flora management, would have been advisable. If local farmers and shepherds had been more involved in negotiations, decision-making and even in the management of the protected area conservation strategies, the park would have saved money and, at the same time, would have had the political consensus in order to contain the power of other political agents. On the contrary, the park managers have been careless about the systematic exclusion of these social groups for too many years. Furthermore, its management has produced a public rhetoric of universal possession of nature in which the end-user of the park is humanity as a whole - travelers, tourists, sportspeople and, of course, ecologists from all over the world. This kind of universalistic rhetoric appears to be fueling a cultural and political conflict between the park and the farmers.

\section{The park's rhetoric and the 'matters of fact'}

The park managers' universalistic conception of the environment as the heritage of humankind seems to be one of the causes of their reduced capacity in dealing with local farmers in order to build consensus on environmental protection policies. In a recent interview, the director of the Monti Sibillini national park argued;

The park has become the opportunity to get out from a narrow localism and to open the territory to a large-scale vision of its problems. Now these territories have left their traditional municipal-based policies to enter a global, complexity-oriented political approach.

This may be the case, but farmers, shepherds and a significant part of the local government officers have been showing their disappointment with this 'large-scale vision' for years, to the point that a wolf's head was found hanging from a road sign in the town of Visso during the winter of 2010. As many studies have shown, it is not surprising that people perpetuate such acts when conservation professionals and state policies fail to address rural poverty and the rights of rural people to make a living from the environment in which they work day by day (Peluso 1992; Bryant 1997; Klooster 2000; Ambinakudige 2011). In the case of the Parco Nazionale dei Monti Sibillini, policies, even in official documents, address nature, wildlife, tourism and cultural goods. Very significantly, no references are made to issues concerning the quality of life of the people living within the boundaries of the park and the acknowledgement of the ecological role of their traditional knowledge and activities. For instance, there are no references to the guidelines and to the principles of the European Landscape Convention (2000), which acknowledges that "all the parties with an interest have the right to participate in the definition and implementation of the landscape policies." So it is not surprising that farmers, a significant part of the local communities directly involved in environmental management, perceive national parks only in terms of their bureaucracy and restrictions, as symbols of injustice and of social inequality.

The current economic crisis is partly responsible. The economic frailty of local rural households has grown remarkably in recent years. The loss of incomes from tourism related activities, the crisis of local manufacturing and of quality food sales, and even cuts to public sector jobs, are affecting a region 
that already had few development chances. The park director's statement is indicative of a discursive strategy constantly adopted by the park administration which indicates many difficulties in addressing some key issues of local social and environmental history.

Official documentation often calls for local communities to be more open, but may be an attempt to explain the hostility of local farmers to environmental restoration programs, making reference to the stereotype of the traditional hostility of mountain people to innovation. Local history does not suggest this, and includes a pattern of permanent and seasonal migration and continuous social, economic and cultural exchanges with surrounding areas and even beyond them (Albera and Corti 2000; Desplanques 1969). During my contacts and interviews with the park managers, I constantly reported a local concern over rules and restrictions. They claim that local farmers and shepherds are not concerned about nature conservation issues but are merely worried about the impact that park rules may have on their economic activities and, at the same time, they affirm that there is no territorial exception here - the implementation of park rules are the same across Italy.

If the managers deem farmers' attitudes towards the environment to be insensitive to nature conservation; again this is a debate about public and private visions for nature. It is ironic that the social history of these mountains has been characterized, since medieval times, by important forms of collective management of land called comunanze. These common properties have always limited private possession of land, integrating pastoral, agricultural and woodland activities, and enforced respect for a constant balance between the number of families and the amount of available land (Papa 1998; Sobrero 1974). The long history of this collective land management system shows it has not always been ecologically sustainable, causing massive deforestation and biodiversity erosion, especially in times of demographic growth (Desplanques 1969). Nonetheless, it is acknowledged as a regulating system focused on natural resource preservation and reproduction in order to sustain families and coming generations (Sereni 2004 [1961]). As numerous studies have demonstrated common property can be "comparable with protected areas in terms of the preservation of forest cover and other measures of biodiversity conservation" (Bray and Velazquez 2009: 12). In particular, in the case of the Apennines and the Alps in Italy, punishments were established for illegal hunting or any other practice that would put the reproduction of natural resources at risk. This is still present, especially among small farmers. Many observers, including a number of ecologists, agree that the main problem within the comunanze is depopulation itself, which is corroding the efficiency of these traditional institutions. Depopulation has caused the weakening of the local informal and institutionalized networks of land control as well as the fading of a shared sense of common interest within local farming and pastoral communities. Nevertheless, the park administration could work towards the renewal and the strengthening of these old institutions, making an effort to defend them from the predatory attitudes of some big entrepreneurial farmers, new and old, who easily find ways to escape the local regulations with negative environmental consequences.

Park managers, instead, insist on the need for these people to become smarter, more open and more dynamic;

The park has a youthful and dynamic message. Within such a territory, sociologically old and culturally conservative, that's why we need a new entrepreneurship, that's why we can count only on the future generations of these local communities. If there would be more young people, we could do many other things.

This statement made by the park director reveals a modernist-reformist concept of the park that is coherent with the aims of a national institution engaged in stimulating long-term local development: a park should be primarily founded on participation of local youth and on innovation.

There are many social and cultural reasons why environmental conservation and sustainable development should become messages shared not only by the young but also by the old generations. First of all, as the park director admits, the local demographic pattern is characterized by an aging population most residents are over 65 - and a generational renewal rate of nearly zero. Young male farmers (30-50 years old), the majority of whom still live alone with their parents, experience enormous difficulties finding a wife. And as we have described, there is a continuous out-migration of young people, in most cases encouraged by their elders. The influence of social solidarity between generations and the pressures exercised by parents on the life choices made by their children should not be trivialized. Excluding the old means excluding the young, and incidents of civil and ecological disobedience are on the rise: a better understanding of the park's new message will not be enough to build social consensus.

A selective reading of the population in terms of age classes is symptomatic of a mechanistic view of history and society. In essentialist terms, park managers usually talk about "inevitable and irreversible processes due to the industrialization in our country", referring to the progressive abandonment of mountainous areas. These words from the park's president allege that these social processes are unavoidable, and local rural communities are incapable of facing modernity. For him, as well as for the park's director, neglected areas in the rural space have to be seen as "positive opportunities to expand nature again": the neglected areas are becoming the future of nature. But nothing has been done to protect and reorganize neglected landscapes, to recover or remove the unused infrastructure or the abandoned buildings left in ruins for years, once so highly criticized by environmentalists. It is not unusual to find 
toxic waste, such as asbestos panels, piles of car batteries and wrecks of refrigerators and other appliances (Piermattei 2011).

From the analysis of statements and official documents produced by the park administration, this rhetoric has to do with a scientific logic of undisputed 'matters of fact', held largely by representatives of natural sciences. When the discourse of ecological science and of its professionals pretends to be neutral and anti-political, in the sense that everything it addresses should be considered as objective, this leads to the cultural marginalization of local knowledge and, thus, to the political marginalization of local communities. French philosopher and sociologist of science Bruno Latour finds these attitudes are obstacles towards a fruitful political ecology (Latour 1999).

'Matters of fact' pervade the entire Italian nature conservation system. In effect, this legislation only focuses on economically marginalized areas (Figure 1). Southern Italy, the Alps, the Apennines, and coastal areas where building tourism facilities would be too expensive, are believed to hold potential for nature or sports based tourism. The more these areas are affected by depopulation the better, in order to easily impose a park with its associated new restrictions on land use and infrastructure. Thus, national parks risk becoming natural ghettos where nature is bounded and ecology itself can be politically marginalized. Meanwhile in the rest of the "national geo-body" (Thongchai 1994), there is no need for environmental protection and Italian and European environmental legislation can be systematically ignored and violated (as testified by the fines of millions of Euros paid by the Italian government to the EU every year because of systematic violations of environmental protection policies). As anthropologist Peter Dwyer suggests, a separation between anthropomorphic spaces and natural worlds, and a systematic specialization of areas within the nation state, is fully coherent with an intensive pattern of resource use that concentrates human activities only in places considered as cost-effective (Dwyer 1996). Thus when the park's former president told me that "The park has not introduced new regulations or restrictions, it simply enforces the rules in effect nationwide", this sound like rhetorical trick to deny a completely different reality, and to use protected areas to legitimate strategic environmental, political and economic discontinuities within the territory.

This is why supposedly anti-political scientific knowledge should be questioned, when it uses political authority. It is precisely this authoritativeness that defines what is natural and what is cultural and, in so doing, cannot leave room for local, indigenous self representations and determinations. It is still modern science that defines, decides and gets things done, even establishing whether or not to give 'others' the chance to talk, and to express in their own voice. Where this happens, protected areas are likely to be viewed with hostility by local communities as signs of social and political inequality, the means of a new kind of despotic 'ecopower'.

Challenging the scientific logic of undisputed 'matters of fact' is not an easy task, especially if we take into account the ambiguous power relationships that cross ecopolitical fields, as I have tried to explain. Nevertheless, a mutual engagement of different forms of knowledge - scientific and local knowledge, and across natural and social sciences - would be helpful to explore what could be a 'good fact', negotiated and discussed from different critical perspectives. Widening Latour's concept of democracy of the sciences and talking more extensively of a democracy of knowledge is required to translate ecology into politics. Sensitive and exigent procedures are required rather than the $a$ priori exclusion of traditional knowledge. New forms of ecopolitical negotiation could begin between the park administration and the local farmers, offering a better consideration of their traditional environmental knowledge and practices. Opinions like "local knowledge is not dynamic and is merely linked to the past, hindering innovation", expressed by many representatives of the park administration, reveal a hegemonic attitude which should not be part of an ecopolitical framework of openness, inclusion and participation. Embracing relationships among different fields of knowledge is the task of the representatives of scientific knowledge.

\section{Conclusions}

The contemporary international debate on community-based conservation has contributed to the emergence of many different positions concerning the efficacy of such programs to promote both nature conservation and local economic development goals (see Langton, Rhea and Palmer 2005; West, Igoe and Brockington 2006; Bray and Velazquez 2009). There are some general considerations that can be considered as points for debate. Firstly, a cooperative resource governance arrangement doesn't automatically mean social equality; rather, it helps to reorient power structures, leading to "to spoils for some and reduced value of access for others" (Annear 2009: 34). We must rely on accurate case studies to uncover these spoils, because, as Tsing reminds us, there is much uncertainty over cooperative decisionmaking models (Tsing 2005). This is because community-based natural resource projects "...won't bring justice to everyone. They embroil participants in debates about authenticity and consensus. They mess with_or displace_-earlier categories and cosmologies; they realign local priorities." (Tsing 2005: 267268). Thus; 
...heterogeneous and unequal encounters can lead to new arrangements of culture and power. [...] 'Communities' are constituted in relation to other kinds of scale-making projects, including bureaucracies, nations and international bodies of power and expertise. Community-making projects may or may not empower local peoples; it all depends on just how this relation is organized: Who benefits? (Tsing 2005: 264)

This leads us to the core of the global environmental debate regarding a real democracy of knowledge in environmental management. It means going beyond the documentation of indigenous knowledge or the criticism of local and trans-local power relations. We need to return to the actors and stakeholders a plurality of perspectives and conceptions implicit within a specific eco-political context, in order to understand the collective experience in which we are all involved. This suggests enriched debate and new visions of how the collectivity itself could be (Latour 1999). As Kay Milton reminds us, it is a specific task of anthropology to use cultural relativism responsibly. We don't understand cultures exclusively in their proper terms, but comprehend them as different ways to see the world, and not as the way things really are (Milton 1996).

A criticism based on a solid and informed technical knowledge is not enough to translate all these considerations in political practice. The contradictions between the official rhetoric of a particular cultural perspective and the forms of social life it influences must be unveiled, observing and re-contextualized within a moral economy of responsibility (Herzfeld 2001). This could be the basis for an assessment within a specific environment of the possible threats to it coming from different social agencies. For instance, in the case we are debating here, a common social responsibility has to be shared between farmers, local government officers and the park management; bottom-up participation should be a key feature of the local political ecology. The preoccupation with conserving environmental heritage is turned into an issue by farmers as well as mayors, park managers and ecologists. There are divergences in how the issues are culturally perceived and elaborated. The fact remains that these concerns are oriented towards concrete issues that involve the management of public and private environmental assets: they are not abstract. There remain divergences in the way the nature of these assets are culturally perceived and elaborated. These different but complementary perspectives should represent wealth for this territory to the extent that together they can contribute to sustainable management of the mountain areas.

It must be acknowledged that, aside from their specific concrete interests, farmers are constantly concerned with the health of the natural environment. It would be fruitful to translate these worries into political and practical involvement, to channel their frustration and their criticisms. When a communitybased conservation program guarantees access to land and is well rooted in a collective sense of selfresponsibility - which means both the ability to exercise governance structures and decision-making authority and to create multi-scalar linkages with national and international bodies of power and expertise - there are positive results in social, cultural and environmental terms. Langton, Rhea and Palmer (2005) show how this can be in their case studies about Indigenous Protected Areas in Australia. It requires;

...the maintenance of the biodiversity related knowledge systems [...] an economically sustainable future through both customary subsistence activities and the negotiated development of their resources within the market economy [...] the establishment or strengthening of land management organizations which have provided the community with employment, increased self esteem, and provided an organization structure which encourages intergenerational dialogue between elders and the youth who are seeking to understand more about their country and the stories and knowledge of the old people. (Langton, Rhea and Palmer 2005: 42)

Such goals could be viable even within the context of the Parco Nazionale dei Monti Sibillini, where there is also a very long tradition of collective properties (the comunanze). Once properly reorganized and re-empowered, collective land management could be one of the best ways to promote participatory forms of self-governance.

In order to make this possible a more general re-configuration of power relationships and bureaucracy is needed, and a cultural re-consideration of both the professional and political roles of ecologists and local government officers. For example, ecologists and administrators should admit their true motivations, whether these are about maintaining political control, economic opportunity, or personal conviction. The ecologist-protectionist discourse is superfluous for nature conservation policy in Monti Sibillini. The historic reality is an area that has always been populated and worked intensively by humans. The park is a form of appropriation of nature (by the park management). Protecting the environment requires the establishment of restrictions, the use of funds and the creation of structures for managing and monitoring. But in order to achieve all this, the work on local political consensus is of fundamental importance. Issues of environmental protection are the output of concrete political negotiations at the time these protection practices are institutionalized. Any park administration should tackle numerous contrasting demands and should build up a political constituency. This could be defined as an ecology of consensus, whose aim is the search for political balance within a diversity of contrasting economic interests. There is a question over the priorities and willingness of park managers: 1) the priority of 
acknowledging and appreciating the ecological role of local farmers, and 2) a willingness to discuss and negotiate a common knowledge and a common set of practices directly with them.

The local political situation does not depend on the park administration's decisions alone. The inadequate funding of national parks in Italy, especially in times of economic recession, is exasperating. Nevertheless, the shift within the political axis of local negotiations, namely from local communities and associations to local government bodies is mainly due to the effects of the application of the Italian legislation on national protected areas in the 1990s. Also evident is the ambiguous role of mayors and of other influential local political actors, who try to create and manage consensus by using this conflictive context in opportunistic terms. They should mediate in transparent and more coherent ways, remembering that a common aim of all the local institutional actors should be to fight against depopulation. Encouraging the younger generations to stay and take care of their homes and their land, and involving them in the management of the protected area, requires money and a reform of the current local administrative framework. Local municipalities should be reduced in number and arranged into broader and more efficient organizations, in order to save money and rationalize local investment. The power of local governments within the park's consultative and legislative bodies needs to be reconsidered. The Italian legislation on protected areas should be reformed to enhance the bottom-up participation of specific groups of interest in proximate communities. In this way, by making the park's organization more efficient and cost-effective and by re-concentrating financial resources on local development and nature conservation, it might even be possible to reduce the high 'costs of politics' in Italy.

In conclusion, it is evident that in the configuration of this scenario there has been very little room for social science professionals to take on roles as consultants and cultural mediators. Local park managers tend to use demographic and quantitative sociological studies that give them no qualitative and meaningful view into the peoples' cultural attitudes and feelings towards the park. It is curious that these social analyses are made by sociologists who are also involved in the park management. Perhaps the time has come to use a team of independent professionals, and to conduct participant ethnographies that are able to intervene in the local debate, and even to suggest concrete solutions to the interested parties.

\section{References}

Agrawal, A. and E. Ostrom. 2001. Collective action, property rights, and decentralization in resource use in India and Nepal. Politics and Society 29(4): 485-514.

Agrawal, A. and K. Redford. 2009. Conservation and displacement: an overview. Conservation and Society 7: 1-10.

Albera, D. and P. Corti. 2000. Movimenti migratori nell'arco alpino e nella montagna mediterranea: questioni e prospettive per un'analisi comparata. In D. Albera and P. Corti (eds.), La montagna mediterranea: una fabbrica d'uomini? Mobilità e migrazioni in una prospettiva comparata (secoli $X V-X X)$. Cavallermaggiore: Gribaudo.

Ambinakudige, S. 2011. National Parks, coffee and NTFPs: the livelihood capabilities of Adivasis in Kodagu, India. Journal of Political Ecology 18: 1-10.

Anderson, D. and E. Berglund (eds.). 2004. Ethnographies of conservation: environmentalism and the distribution of privilege. Oxford: Berghahn Books.

Annear, C. 2009. Navigating constricted channels: local cooption, coercion, and concentration under comanagement, Mweru-Luapula fishery, Zambia. Journal of Political Ecology 16: 34-48.

Berkes, F. 2004. Rethinking community-based conservation. Conservation Biology 18(3): 621-630.

Brookfield, H.C. 2001. Exploring agrodiversity. New York: Columbia University Press.

Bray, D. and A. Velazquez. 2009. From displacement-based conservation to place-based conservation. Conservation and Society 7: 11-14.

Bryant, R. 1997. The political ecology of forestry in Burma 1824-1994. Honolulu: University of Hawaii Press.

Desplanques, H. 1969. Campagnes ombriennes: contribution à l'étude des paysages ruraux en Italie centrale. Paris: Colin.

Dowie, M. 2005. Conservation refugees: when protecting nature means kicking people out. Orion Magazine online (accessed May 15, 2013).

Dwyer, P.D. 1996. The invention of nature. In R. F. Ellen and K. Fukui (eds.) Redefining nature: ecology, culture and domestication. Oxford: Berg.

English, A. 2000. An emu in the hole: exploring the link between biodiversity and aboriginal cultural heritage in New South Wales, Australia. Parks 10:13-25.

European Landscape Convention 2000. The European landscape convention. Florence: European Union. 20/10/2000.

Freedman, E. 2002. When indigenous rights and wilderness collide: prosecution of Native Americans for using motors in Minnesota's Boundary Waters Canoe Wilderness Area. The American Indian Quarterly 26: 378-392. 
Greenough, P. 2003. Pathogens, pugmarks, and political emergency: the 1970s South Asian debate on nature. In P. Greenough and A. Tsing 2003 (eds.) Nature in the Global South: environmental projects in South and South East Asia. Durham, NC: Duke University Press. Pp. 201-230.

Greenough, P. and A. Tsing (eds.) 2003. Nature in the Global South: environmental projects in South and South East Asia. Durham, NC: Duke University Press.

Hartog, F. 2003. Régimes d'historicité: présentisme ed expériences du temps. Paris: Éditions du Seuil.

Heatherington, T. 2010. Wild Sardinia: indigeneity and the global dreamtimes of environmentalism. Seattle: University of Washington Press.

Herzfeld, M. 1992. The social production of indifference: exploring the symbolic roots of western bureaucracy. Oxford: Berg.

Herzfeld, M. 2001. Anthropology: theoretical practice in culture and society. Oxford: Blackwell Publishers.

Holt, F.L. 2005. The catch-22 of conservation: Indigenous peoples, biologists and culture change. Human Ecology 33: 199-215.

Igoe, J. 2003. Scaling up civil society: donor money, NGOs and the pastoralist land rights movement in Tanzania. Development and Change 34:863-885

Klooster, D. 2000. Institutional choice, community, and struggle: a case study of forest co-management in Mexico. World Development 28:1-20.

Langton, M.L., Z.M. Rhea and L.R. Palmer. 2005. Community-oriented protected areas for Indigenous peoples and local communities. Journal of Political Ecology 12: 23-50.

Latour, B. 1999. Politiques de la nature. Paris: Éditions La Decouverte \& Syros.

McLean, J. and S. Straede. 2003. Conservation, relocation and the paradigms of park and people management: a case study of Padampur villages and the Royal Chitwan National Park, Nepal. Society and Natural Resources 16: 509-526.

Milton, K. 1996. Environmentalism and cultural theory: exploring the role of anthropology in environmental discourse. London: Routledge.

Nardoni, M. 1999. Sibillini: storia di un parco. Ascoli Piceno: CAI.

Papa, C. 1993. Il lupo tra realtà e rappresentazione in un'area appenninica destinata a parco naturale. In S. D'Onofrio (ed.) La cultura del bosco. Palermo: Laboratorio Antropologico Universitario.

Papa, C. 1998. Il farro a Monteleone di Spoleto: pratiche agrarie, consuetudini giuridiche e ritualità. In C. Papa (ed.) Il farro. Saperi, usi e conservazione delle varietà locali. Cerreto di Spoleto: CEDRAV.

Papa, C. 1999. Antropologia dell'impresa. Milano: Guerini.

Papa, C. 2004. The conservation of environmental resources. In G. Sanga and G. Ortalli (eds.) Nature knowledge. Oxford: Berg.

Papa, C. 2006. Paesaggi e formaggi. Un'assonanza non casuale nella Valnerina umbra. SM Annali Di San Michele 19: 341-354.

Papa, C. 2009. Il paesaggio come farsi delle popolazioni locali. In A. Branda and I. Cuceu (eds.) Romania Occidentalis - Romania Orientalis: volum omagial dedicat prof. Univ. Dr. Ion Talos. Cluj Napoca: Editura fundatiei pentru studii Europen - Editura Mega.

Peluso, N.L. 1992. Rich forests, poor people: resource control and resistance in Java. Berkeley: University of California Press.

Piermattei, S. 2005. Le risorse genetiche agrarie: aspetti socio-culturali e problematiche della ricerca e della documentazione antropologica. In M. Falcinelli (ed.) La biodiversità vegetale in Umbria e la sua conservazione. Pantalla: Edizioni 3A-PTA.

Piermattei, S. 2006. Some reflections on the agricultural sustainability of nature conservation policies: ecopolitical strategies in the National Park of Sibylline Mountains (Italy). In P. Simonič (ed.), Ethnography of protected areas: endangered habitats - endangered cultures. Ljubljana: Univerza v Ljubljani, Filozofska fakulteta, Oddek za etnologijo in kulturno antropologijo. Review

Piermattei, S. 2007. Antropologia ambientale e paesaggio agrario. Perugia: Morlacchi Editore.

Piermattei, S. 2011. Le "case al mare" a Civita di Cascia. Estetiche e pratiche di una ricostruzione postterremoto tra liminalità, nonluoghi e terzo paesaggio. In F. Lai and N. Breda (eds.) Antropologia del terzo paesaggio. Roma: CISU.

Rao K.S., R.K. Maikhuri, S. Nautiyal and K.G. Saxena. 2002. Crop damage and livestock depredation by wildlife: a case study from Nanda Devi Biosphere Reserve. Journal of Environmental Management 66(3): 317-327.

Sereni, E. 2004 [1961]. Storia del paesaggio agrario italiano. Bari: Laterza.

Sobrero, A. 1974. Proprietà pubblica e privata in alcune comunità rurali dell'Umbria (sec. XV-XVIII). Rivista di Sociologia, 28: 71-88.

Thongchai, W. 1994. Siam mapped: a history of the geo-body of a nation. Honolulu: University of Hawaii Press.

Tsing, A. L. 2005. Friction: an ethnography of global connection. Princeton: Princeton University Press. 
Vaccaro I. and O. Beltran. 2010. Conservationist governmental technologies in the Western European Mountains: the unfinished transformation of the Pyrenees. Journal of Poltical Ecology 17: 28-41.

Vaccaro, I., O. Beltran and P.A. Paquet. 2013. Political ecology and conservation policies: some theoretical genealogies. Journal of Political Ecology 20: 255-272.

West, P.C., J. Igoe, and D. Brockington. 2006. Parks and peoples: the social impact of protected areas. Annual Review of Anthropology 35: 251-277.

\begin{abstract}
Italy has suffered severe depopulation of its mountains over the past six decades. National and European environmental legislation has been aiming to arrest depopulation by promoting local economic development as well as nature conservation. Cultural and social struggles remain between managers of the protected areas and local populations. By exploring the conflict in the Parco Nazionale dei Monti Sibillini, a protected area in the Central Apennines, this work reveals how professional ecologists seem to conceive a universalistic form of possession and management of nature that excludes local traditional uses and knowledge. The needs and expectations of the local communities are overlooked and the bureaucratized forms of nature protection, in addition to the continuous, strenuous political negotiations between the park and the local administrations, tend to nourish feelings of disillusion and hostility towards the park. Perhaps, the time has come to affirm a principle of democracy of knowledge and the need for a participative political ecology.
\end{abstract}

Key words: European protected areas; mountain areas; depopulation; community; agriculture.

\title{
Résumé
}

En Italie, au cours des soixante dernières années les montagnes furent dépeuplée massivement. La législation nationale et européenne de l'environnement a essayé d'arrêter cette dépopulation par la promotion du développement local et de la conservation des ressources naturelles. Cependant, la mise en place de cette politique a produit des conflits culturels et sociaux entre les gestionnaires des aires protégées et les populations locales. A travers l' analyse des conflits dans le Parc National des Monts Sibillini, une zone protégée dans l' Apennin central en Italie, ce travail montre comment les écologistes semblent partager une conception universaliste du patrimoine et de la gestion de la nature qui exclut les pratiques et les savoirs traditionnels. Les besoins et les attentes des communautés locales sont négligées et les formes bureaucratiques de conservation de la nature, en plus des négociations politiques dures et continues entre le Parc et les pouvoirs locaux, produisent des sentiments de désillusion et d'hostilité à l'égard du Parc. Peut-être le moment est venu d'affirmer un principe de démocratie de la connaissance et la nécessité d' une ecologie politique participative.

Mots clés: Les aires protégées, le développement durable, les savoirs locales, la conservation de la nature, l'écologie politique

\section{Riassunto}

In Italia si è assistito a un intenso spopolamento della montagna negli ultimi 60 anni. La legislazione ambientale nazionale ed europea ha cercato di frenare lo spopolamento attraverso la promozione dello sviluppo locale e della conservazione delle risorse naturali. Tuttavia esistono conflitti culturali e sociali tra i manager delle aree protette e popolazioni locali. Attraverso l'analisi del conflitto nel Parco nazionale dei monti Sibillini, un' area protetta nell' Appennino centrale, questo lavoro mostra come gli ecologisti sembrano condividere una concezione universalistica di possesso e gestione della natura che esclude gli usi e i saperi tradizionali. I bisogni e le aspettative delle comunità locali sono trascurati e forme burocratizzate di protezione della natura in aggiunta a negoziazioni politiche dure e continue tra il Parco e le amministrazioni locali, tendono ad alimentare sentimenti di disillusione e ostilità nei confronti del Parco. Forse è venuto il tempo di affermare un principio di democrazia della conoscenza e il bisogno di una ecologia politica partecipata.

Parolechiave: Aree protette, sviluppo sostenibile, saperi locali, conservazione della natura, ecologia politica 